\title{
Relationship Between Climatic Factors and Distribution of Pratylenchus spp. in the Dryland Wheat-Production Areas of Eastern Washington
}

\author{
Shyam L. Kandel, Department of Plant Pathology, Washington State University, Pullman 99164-6430; Richard W. Smiley, Columbia \\ Basin Agricultural Research Center, Oregon State University, Pendleton 97801; Kimberly Garland-Campbell, United States Depart- \\ ment of Agriculture-Agricultural Research Service (USDA-ARS), Wheat Genetics, Quality, Physiology and Disease Research Unit, \\ Pullman, WA 99164; Axel A. Elling, Department of Plant Pathology, Washington State University; John Abatzoglou, Department of \\ Geography, University of Idaho, Moscow 83844; David Huggins, USDA-ARS Land Management and Water Conservation Research \\ Unit, Pullman, WA 99164; Richard Rupp, Department of Crop and Soil Sciences, Washington State University, Pullman; and Timothy \\ C. Paulitz, USDA-ARS, Root Disease and Biological Control Research Unit, Pullman, WA 99164
}

\begin{abstract}
Kandel, S. L., Smiley, R. W., Garland-Campbell, K., Elling, A. A., Abatzoglou, J., Huggins, D., Rupp, R., and Paulitz, T. C. 2013. Relationship between climatic factors and distribution of Pratylenchus spp. in the dryland wheat-production areas of eastern Washington. Plant Dis. 97:14481456.

Field surveys were conducted by collecting soil samples to estimate nematode densities in soil from winter wheat, spring wheat, spring barley, and spring legumes (lentil, chickpea, and pea) fields during 2010 and 2011. Pratylenchus spp. were observed in 60\% of sampled fields. However, nematodes were detected in nearly all of the survey fields in high numbers where crops were grown every year. To identify climatic variables associated with density of Pratylenchus spp. in soil, correlation and regression analyses were performed using climate data of survey sites from 1979 to 2010 . Fifty-seven climate variables were significantly correlated with densities of Pratylenchus spp. All precipitation variables were significantly positively correlated with nematode

abundance. Summer maximum air temperature was negatively correlated and winter minimum air temperature was positively correlated with nematode densities. In addition, both years' nematode densities were significantly correlated with cropping intensity. Five multivariate regression models for 2010 and seven models for 2011 nematode abundance levels were developed. The majority of the climate variables selected in the models were related to precipitation. Knowledge of root-lesion nematode distribution in the dryland region of eastern Washington and associated climate variables may be helpful to determine risk and apply management practices to minimize crop damage.
\end{abstract}

Wheat (Triticum aestivum L.) cultivation in the Pacific Northwest (PNW) of the United States initially started in the late nineteenth century. Average farm size and wheat productivity have greatly increased from 65 to 1,400 ha and from less than $1 \mathrm{t} / \mathrm{ha}$ to $3.4 \mathrm{t} / \mathrm{ha}$, respectively, from that time to the present (40). Wheat is currently grown on nearly 1.85 million ha, with average production of 8.6 million tons every year in the PNW states of Idaho, Oregon, and Washington (52). Approximately $60 \%$ of the wheat in the PNW is grown in a dryland production system with limited amounts of precipitation. A Mediterranean-type climate is dominant throughout the region with hot, dry summers and cool, moist winters. Nearly two-thirds of the precipitation occurs during the winter between October and March and one-fourth of the precipitation occurs during the spring and summer between April and June $(36,40)$. About $90 \%$ of the dryland farming in the low-precipitation (150 to $300 \mathrm{~mm}$ ) area is characterized by a 2-year crop rotation, where a 10-month growing season of winter wheat is alternated with a 14-month fallow period (45). However, in the high-precipitation (400 to $600 \mathrm{~mm}$ ) area, a winter wheat, spring cereal, and spring pulse or brassica rotation is common.

Soilborne pathogens are common in cropping systems where cereals are the major component of the rotation. The effects of diseases caused by soilborne pathogens and nematodes are more evident in rainfed conditions that become water-limited because

Corresponding author: T. C. Paulitz, E-mail: paulitz@wsu.edu

Accepted for publication 7 May 2013.

http://dx.doi.org/10.1094/PDIS-11-12-1060-RE

This article is in the public domain and not copyrightable. It may be freely reprinted with customary crediting of the source. The American Phytopathological Society, 2013. damaged root systems cannot draw moisture and nutrients sufficiently from the soil profile. Enhanced effects of dryland crown rot (Fusarium spp.), common root rot (Cochliobolus sativus), cyst (Heterodera spp.), and root-lesion nematodes (Pratylenchus spp.) are often observed when plants are under moisture stress (11).

Pratylenchus spp. are polyphagous, migratory ecto/endoparasites with a near cosmopolitan distribution. They feed on and damage plant roots, resulting typically in small lesions on young feeder roots at first and larger lesions later along the root axis $(28,49)$. Aboveground symptoms caused by Pratylenchus spp. in cereal crops are often confused with nutrient deficiency, moisture stress, or attack of soilborne fungi such as Fusarium, Pythium, and Rhizoctonia spp. (44). Damaged plants become stunted, chlorotic, and wilted during hot summers $(33,38)$. Pratylenchus neglectus and $P$. thornei are major parasites of wheat, and are found in all wheat-growing regions of the world (30). In the PNW states, nearly $90 \%$ of surveyed fields were infested with $P$. neglectus and $P$. thor$n e i$. In addition, more than $60 \%$ of those fields showed economically damaging population levels of one or both species $(46,48)$. $P$. neglectus and $P$. thornei cause up to $5 \%$ crop loss every year in the PNW (43). P. thornei has been documented to reduce crop yield up to $70 \%$ on intolerant wheat cultivars in northern Australia (49), $29 \%$ on intolerant susceptible wheat cultivars in Mexico (29), and up to $70 \%$ in arid dryland regions of Israel (34). P. neglectus reduced wheat yield by 10 to $30 \%$ in southern Australia (54) and causes significant yield reductions in the PNW of the United States (45).

Damage caused by plant-parasitic nematodes depends on many variables, including host susceptibility, population densities in the soil, mode of parasitism, number of generations during the growing period, and environmental factors $(3,15,58)$. The effect of environmental factors such as soil moisture and temperature, soil texture, and rainfall on pathogenicity and populations has been documented for many plant-parasitic nematodes $(15,19,21,59)$. P. neglectus 
populations were considerably influenced by soil moisture in wheat (21). Similar effects of soil temperature, soil $\mathrm{pH}$, and soil type also have been studied in other species of Pratylenchus $(9,14,15,22,59)$.

A healthy root system is essential for small grain crops to draw soil moisture from deeper soil profiles under dryland conditions. No methods of chemical control of plant-parasitic nematodes are available for cereal crops in the PNW, and adapted resistant cultivars are not yet available. Cultural practices of crop husbandry such as crop rotation and cropping system can have an effect on nematode populations in the soil. Precise assessment of parasitic nematodes in the soil may allow growers to anticipate potential crop losses before planting and make management decisions to minimize the crop loss (37). Moreover, the effect of climatic factors on the PNW populations of Pratylenchus spp. has not been studied yet. The objectives of this study were to identify and quantify Pratylenchus spp. in eastern Washington, and to determine the major climatic variables influencing these nematode populations in the soil.

\section{Materials and Methods}

Soil sample collection. Field surveys for Pratylenchus spp. were conducted by collecting soil samples from Washington State University Extension Cereal Variety Trials and from growers' fields during mid-May to mid-June in 2010 and 2011. In all, 90 soil samples in 2010 and 84 samples in 2011 were collected from fields in which major dryland crops, including winter wheat, spring wheat, spring barley, spring chickpea, spring lentil, and alfalfa, were grown. The same farms were sampled both years but often an adjacent field had to be sampled the second year to keep the same rotation. The root zone soil along with plants was removed by shovel from $0-$ to $25-\mathrm{cm}$ depths and collected in polyethylene bags. Three soil samples in each field were taken starting 100 paces away from the border and walking 25 more paces in a zigzag pattern between the next two samples. The three subsamples were mixed in one bag and taken as one sample from each respective field. Survey sites were located in Whitman, Adams, Walla Walla, Spokane, Lincoln, Grant, Columbia, Douglas, and Franklin Counties, representing the six major PNW agronomic zones described by Douglas et al. (10).

Nematode extraction. All collected soil samples from field surveys were stored at $4{ }^{\circ} \mathrm{C}$ before being sent to Western Laboratories, Parma, ID to extract Pratylenchus spp. and other plant-parasitic nematodes. A modified elutriation method (17) was used to extract nematodes from $250-\mathrm{cm}^{3}$ subsamples. The soil was placed on a $35-$ mesh $(500-\mu \mathrm{m})$ sieve and washed into a modified Oostenbrink elutriator. Soil on the sieve was dispersed by a water spray to dislodge the nematodes from soil. The suspension collected in the funnel was passed through a set of four sieves. The upper two were 400-mesh $(38-\mu \mathrm{m})$ and lower two were 450-mesh $(32-\mu \mathrm{m})$ sieves. Sieves were washed immediately with a small amount of water and the nematodes were collected in a cup. The nematodes settled for about $2 \mathrm{~h}$ and then the upper layer of water was siphoned off to retain the nematode suspension at the bottom of the cup. The nematode suspension was then transferred to a 50-ml centrifuge tube and centrifuged at $1,800 \times g$ for $5 \mathrm{~min}$. After centrifuging, the supernatant was poured off and the pellet was retained in the tube. The pellet was resuspended in a magnesium sulfate solution adjusted to specific gravity of 1.18. The suspension was then centrifuged at $1,800 \times g$ for $4 \mathrm{~min}$ to float the nematodes in the magnesium sulfate solution. Nematodes suspended in the top layer were passed through a 635-mesh $(20-\mu \mathrm{m})$ sieve, the sieve was washed with a small amount of water, and nematodes were collected in a 50-ml plastic centrifuge tube. The nematodes were counted under a microscope and reported as nematode density per $500 \mathrm{~cm}^{3}$ of soil. For quantifying cereal cyst nematodes, similar methods were used to extract cysts, which were crushed to count eggs and juveniles.

Geospatial referencing of survey sites. Latitude and longitude coordinates in degrees, minutes, and seconds were recorded for every collection site and converted to decimal degrees. Nematode densities for both 2010 and 2011 were plotted in different agroclimatic zones of eastern Washington described by Douglas et al. (10) using ArcMap version 9.3 (ESRI).

Meteorological and cropping intensity data. In the past, meteorological data relied on the use of local surface meteorological observations from weather stations. These stations are often far apart and fail to cover an entire area of geographic interest. Various interpolation methods can be used to model and derive the probable values in the areas between the weather stations. A high-resolution daily meteorological dataset scaled to $4 \mathrm{~km}$ covering the survey area for the time period 1979 to 2010 was developed by Abatzoglou (1) and was used in this work. Average precipitation and minimum and maximum air temperature per month were calculated using 31 years (1979 to 2010) of weather data averaged for each of 12 months. In addition, 2-month and 3-month average precipitation and minimum and maximum air temperature of the wheat-growing period (October to June) were calculated using average monthly readings of that period. The 2010 and 2011 monthly values averaged across all sites were compared with the 30 -year averages to determine how these two years compared with the long-term trends.

Cropping intensities of survey locations in 2010 and 2011 were calculated from the pixel intensity of data layers on raster of a cropping-intensity model developed by R. Rupp and D. Huggins, using the National Agricultural Statistic Service Crop Layer product, derived from satellite imagery in 2007. Intensity was based on the probability of that field being cropped in a given year. If a field was cropped every year, the cropping intensity was $100 \%$; if cropped every other year, the intensity was $50 \%$; and, if cropped 2 of 3 years, the intensity was $66 \%$.

Data analysis. Pearson's correlation coefficients were calculated comparing the 2010 and 2011 Pratylenchus spp. population levels and monthly average, 2-month average, and 3-month average precipitation and minimum and maximum air temperatures. Nematode counts were transformed to $\log _{10}(X+1)$ before analysis for both years $(21,25)$. Weather variables that were significantly correlated with both 2010 and 2011 nematode densities were included in multiple linear regression models. The predictor variables in regression models were identified through stepwise regression. The best subset regression algorithm was used to develop models using significantly correlated predictor variables. Mallows' $C_{p}$ statistic, which displays goodness of fit of the regression equations, and the adjusted coefficient of multiple determination $\left(R^{2}\right)$, which depicts the independent variables associated with total variation of a dependent variable, were reported for each model (42). The prediction sum of squares (PRESS) statistic, which describes the predictive power of a model, was calculated by repeatedly leaving out an observation for every repetition, similar to a bootstrap analysis. In regression analysis, the PRESS statistic is independent of observed responses and represents a true measurement of the prediction accuracy of the regression model (27). Regression models having relatively small PRESS values are considered the best models because of small prediction errors (23). If the independent variables included in a regression model are highly significantly correlated, this collinearity will cause instability in the regression model. The variance inflation factor (VIF) quantifies the degree of multicollinearity among the explanatory variables in a multiple regression analysis. Explanatory variables with a high VIF and low regression sum of squares are generally excluded from the model. A multicollinearity test was conducted as indicated by variance inflation factors (23).

\section{Results}

Pratylenchus spp. density in 2010. In 2010, Pratylenchus spp. were detected in $66 \%$ of sampled fields. They were observed throughout the dryland wheat-production areas of eastern Washington, and found in fields currently planted to winter wheat, spring wheat, spring barley, and spring legumes (chickpea, lentil, and pea). Nematodes were observed in all agronomic zones but populations declined from annual crop-wet-cool (zone 2) to the driest 
parts (irrigated [zone 6] and grain-fallow [zone 5]) of the state (Fig. 1). Nematode density and incidence were relatively high in annual crop-wet-cool (zone 2), an annual cropping area where spring crops such as wheat, barley, and different legumes are grown in rotation with winter wheat.

Density of Pratylenchus spp. in 2011. In 2011, Pratylenchus spp. were present in $57 \%$ of sampled fields. Infested crop fields were planted to winter wheat, spring wheat, spring barley, spring legumes (chickpea, lentil and pea), and winter canola. Higher nematode density and higher incidence were found in annual crop fallow transition (zone 2), with a similar distribution as in the 2010 survey (Fig. 2).

Other plant-parasitic nematodes in 2010 and 2011. The cereal cyst nematode (Heterodera avenae), stunt nematode (Tylenchorhynchus spp.), pin nematode (Paratylenchus spp.), and Columbia root-knot nematode (Meloidogyne chitwoodi) were found in a few fields in addition to Pratylenchus spp. H. avenae was found in approximately $12 \%$ of total sampled fields, where population density varied from 10 to 1,920 eggs and juveniles per $500 \mathrm{~cm}^{3}$ of soil. The stunt nematode (Tylenchorhynchus spp.) was detected in approximately $27 \%$ of sampled sites, with an average density of 325 nematodes per $500 \mathrm{~cm}^{3}$ of soil. The pin nematode (Paratylenchus spp.) was observed in $12 \%$ of sampled fields, with an average population of 440 nematodes per $500 \mathrm{~cm}^{3}$ of soil. The Columbia rootknot nematode (M. chitwoodi) was found in less than $1 \%$ of sampled sites, with an average density of 20 nematodes per $500 \mathrm{~cm}^{3}$ of soil.

Correlations between Pratylenchus spp. density and mean maximum temperatures. The first year of the study was characterized by warmer January and February temperatures but significantly cooler conditions in May and June (Table 1). Similarly, 2011 was also characterized by a cool spring and early summer (April to July). Eleven maximum air temperature-based variables were significantly negatively correlated with Pratylenchus spp. densities in 2010. Eight maximum air temperature-based variables were significantly positively correlated with 2011 nematode densities and only five were negatively correlated (Table 2). Maximum air temperature in April through September, March and April to May and June, and March to May and April to June were significantly negatively correlated with 2010 Pratylenchus spp. densities; and May to June, April and May to May and June, and April to June maximum air temperature were significantly negatively correlated with 2011 Pratylenchus spp. densities. The maximum air temperature in January, December, November and December to January and February, and October to December through December to February were significantly positively correlated with 2011 nematode densities (Table 2).

Correlations between Pratylenchus spp. density and mean minimum temperatures. None of the minimum air temperaturebased variables were significantly correlated with 2010 Pratylenchus spp. density. However, 1-month minimum air temperaturebased variables for January, February, November, and December; 2-month variables for November and December through January and February; and 3-month variables for October to December through January to March were significantly positively correlated with 2011 Pratylenchus spp. densities (Table 2).

Correlations between Pratylenchus spp. density and monthly precipitation. The first year of the study was characterized by a significantly wetter spring (April, May, and June) than the longterm average (Table 1). Similarly, 2011 also had a wetter spring from March to May. All precipitation-based variables were significantly correlated during both years with Pratylenchus spp. densities (Table 2). The 1-month variables for January to December, 2month variables for October and November to May and June, and 3-month variables for October to December through April to June were significantly correlated with 2010 and 2011 Pratylenchus

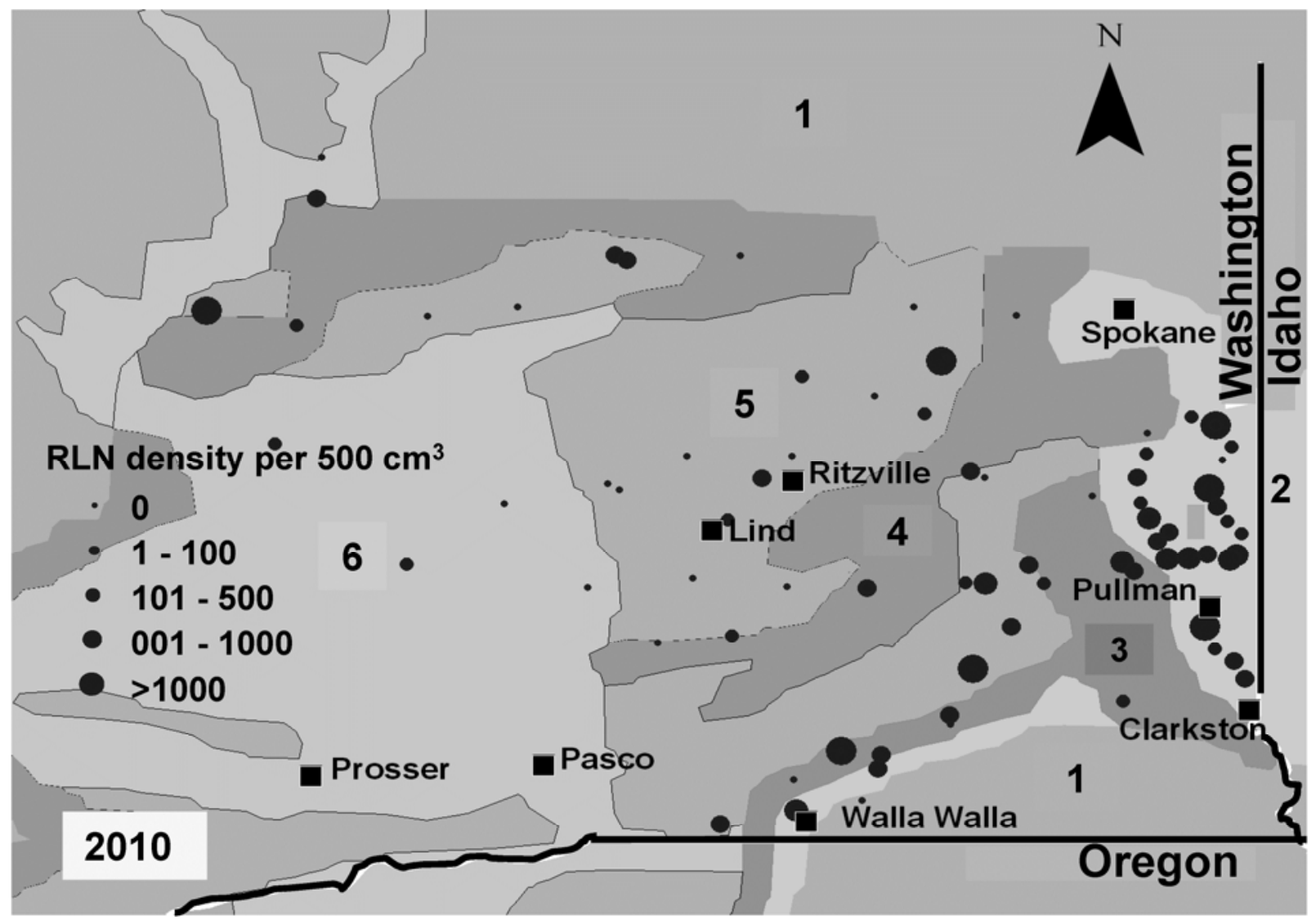

Fig. 1. Pratylenchus spp. density per $500 \mathrm{~cm}^{3}$ of soil in late spring 2010 in different agroclimatic zones of eastern Washington. Agroclimatic zones are represented by color areas: 6 = irrigated, $5=$ grain-fallow, $4=$ annual crop-dry, $3=$ annual crop-fallow-transition, $2=$ annual crop-wet-cool, and $1=$ annual crop-wet-cold. RLN = root lesion nematode. 
spp. densities (Figs. 3 and 4). The majority of the survey fields in low-precipitation areas showed the absence of Pratylenchus spp.

Correlations between 2010 and 2011 Pratylenchus spp. density and cropping intensity. The Pratylenchus spp. density in 2010 was significantly correlated $(r=0.394 ; P<0.001)$ with the 2011 density. Cropping intensity was also significantly correlated with the 2010 and 2011 Pratylenchus spp. densities $(r=0.336 ; P=$ 0.003 and $r=0.403 ; P<0.001$, respectively; Fig. 5). No Pratylenchus spp. were detected in most of the fields in wheat-fallow areas where cropping intensity was low.

Multiple linear models developed for 2010 Pratylenchus spp. density. All 37 significantly correlated variables were subjected to a stepwise regression to select variables that explained the nematode density. Four explanatory variables were selected from stepwise regressions. These were all precipitation-based variables and had higher correlation coefficients than air temperature-based variables (Table 3). Five multiple linear regression models (models 1 to 5) were developed using the selected four variables through the best subset algorithm. The higher VIF values in models indicated the multi-collinearity among weather variables resulting in lower adjusted $R^{2}$ and higher PRESS values. The relatively low $R^{2}$ values and high PRESS values in 2010 compared with 2011 indicated that these models were less predictive of nematode density in this year. Nematode densities in soil are not simply influenced by environmental variables but also by other soil and crop factors.

Multiple linear models developed for 2011 Pratylenchus spp. density. A stepwise regression was performed to identify variables that best explained nematode density, including all 50 significantly correlated variables. December and January air maximum temperature; December and January minimum air temperature; and September, October, and December to January precipitations were selected as five explanatory variables from stepwise regressions (Table 4). Seven multiple linear regression models (models 1 to 7 ) were developed taking the five variables selected using the best subset algorithm. The higher VIF values in some models indicated that the multi-collinearity among weather variables resulted in low adjusted $R^{2}$ and higher PRESS values.

\section{Discussion}

Pratylenchus spp. were detected in approximately $60 \%$ of dryland fields in eastern Washington. The incidence and densities of root-lesion nematodes were higher in spring wheat compared with winter wheat and distributed differently in six agronomic zones of eastern Washington. More than $85 \%$ of sampled fields in the annual crop-wet-cool zone were infested with Pratylenchus spp. This zone is characterized by relatively high precipitation $(>400 \mathrm{~mm}$ per year) and an annual cropping system (10). Spring wheat and spring legumes are grown every year in this zone and these crops are good

Table 1. Deviation of 2010 and 2011 mean monthly temperatures and precipitation from 30-year means

\begin{tabular}{|c|c|c|c|c|}
\hline \multirow[b]{2}{*}{ Month } & \multicolumn{2}{|c|}{$\begin{array}{c}\text { Mean temperature }\left({ }^{\circ} \mathrm{C}\right) \\
\text { difference from } \\
\text { 30-year mean }\end{array}$} & \multicolumn{2}{|c|}{$\begin{array}{l}\text { Total precipitation } \\
\text { proportion of } \\
\text { 30-year mean }\end{array}$} \\
\hline & 2010 & 2011 & 2010 & 2011 \\
\hline January & 3.40 & 0.99 & 1.03 & 1.05 \\
\hline February & 2.43 & -1.82 & 0.71 & 0.76 \\
\hline March & 0.40 & -0.33 & 0.61 & 1.73 \\
\hline April & -0.45 & -2.91 & 1.27 & 1.32 \\
\hline May & -2.25 & -1.46 & 1.35 & 1.66 \\
\hline June & -1.29 & -0.93 & 1.90 & 0.77 \\
\hline July & -0.41 & -1.66 & 0.58 & 0.65 \\
\hline August & -0.82 & 0.80 & 0.41 & 0.14 \\
\hline September & -0.59 & 2.57 & 1.86 & 0.26 \\
\hline October & 0.86 & 0.09 & 1.34 & 0.93 \\
\hline November & -1.50 & -0.00 & 0.98 & 0.60 \\
\hline December & 0.63 & 0.85 & 1.36 & 0.52 \\
\hline
\end{tabular}

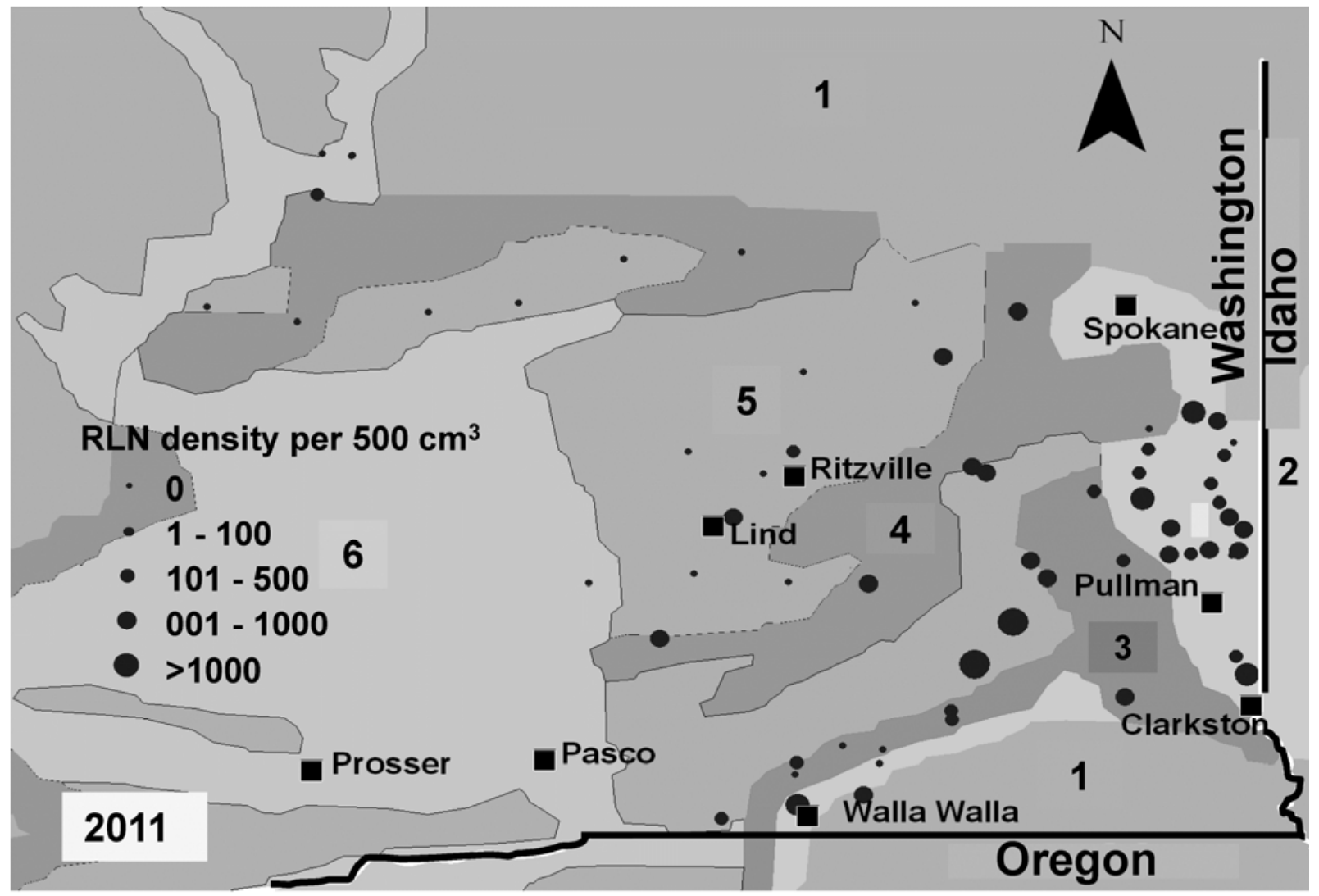

Fig. 2. Pratylenchus spp. density per $500 \mathrm{~cm}^{3}$ of soil in late spring 2011 in different agroclimatic zones of eastern Washington. Agroclimatic zones are represented by color areas: 6 = irrigated, 5 = grain-fallow, $4=$ annual crop-dry, $3=$ annual crop-fallow-transition, $2=$ annual crop-wet-cool, and $1=$ annual crop-wet-cold. RLN = root lesion nematode. 
Table 2. Time periods for which significant correlation coefficients were obtained between weather variable averages (1979 to 2010 ) and 2010 and 2011 Pratylenchus spp. density in soils sampled in the late spring ${ }^{\mathrm{a}}$

\begin{tabular}{|c|c|c|c|c|c|}
\hline \multirow[b]{2}{*}{ Climate variables } & \multirow[b]{2}{*}{ Variable } & \multicolumn{2}{|c|}{2010 density } & \multicolumn{2}{|c|}{2011 density } \\
\hline & & $r$ & $P$ & $r$ & $P$ \\
\hline \multicolumn{6}{|l|}{ Mean maximum temperature } \\
\hline \multicolumn{6}{|l|}{ One-month } \\
\hline January & $\mathrm{X}_{1}$ & 0.171 & 0.107 & 0.349 & 0.002 \\
\hline April & $\mathrm{X}_{2}$ & -0.305 & 0.003 & -0.205 & 0.075 \\
\hline May & $\mathrm{X}_{3}$ & -0.337 & 0.001 & -0.260 & 0.023 \\
\hline June & $\mathrm{X}_{4}$ & -0.334 & 0.001 & -0.268 & 0.019 \\
\hline July & $\mathrm{X}_{5}$ & -0.289 & 0.006 & -0.206 & 0.075 \\
\hline August & $\mathrm{X}_{6}$ & -0.282 & 0.007 & -0.168 & 0.148 \\
\hline September & $\mathrm{X}_{7}$ & -0.252 & 0.016 & -0.148 & 0.201 \\
\hline December & $\mathrm{X}_{8}$ & 0.171 & 0.106 & 0.358 & 0.002 \\
\hline \multicolumn{6}{|l|}{ Two-month } \\
\hline November-December & $\mathrm{X}_{9}$ & 0.096 & 0.369 & 0.286 & 0.012 \\
\hline December-January & $\mathrm{X}_{10}$ & 0.172 & 0.106 & 0.355 & 0.002 \\
\hline January-February & $\mathrm{X}_{11}$ & 0.094 & 0.380 & 0.283 & 0.013 \\
\hline March-April & $\mathrm{X}_{12}$ & -0.253 & 0.016 & -0.130 & 0.263 \\
\hline April-May & $\mathrm{X}_{13}$ & -0.322 & 0.002 & -0.240 & 0.037 \\
\hline May-June & $\mathrm{X}_{14}$ & -0.336 & 0.001 & -0.267 & 0.020 \\
\hline \multicolumn{6}{|l|}{ Three-month } \\
\hline October-November-December & $\mathrm{X}_{15}$ & 0.096 & 0.369 & 0.286 & 0.012 \\
\hline November-December-January & $\mathrm{X}_{16}$ & 0.121 & 0.254 & 0.308 & 0.007 \\
\hline December-January-February & $X_{17}$ & 0.121 & 0.257 & 0.310 & 0.006 \\
\hline March-April-May & $\mathrm{X}_{18}$ & -0.283 & 0.007 & -0.177 & 0.127 \\
\hline April-May-June & $\mathrm{X}_{19}$ & -0.327 & 0.002 & -0.250 & 0.029 \\
\hline \multicolumn{6}{|l|}{ Mean minimum temperature } \\
\hline \multicolumn{6}{|l|}{ One-month } \\
\hline January & $\mathrm{X}_{20}$ & 0.162 & 0.128 & 0.342 & 0.003 \\
\hline February & $X_{21}$ & 0.058 & 0.588 & 0.233 & 0.042 \\
\hline November & $\mathrm{X}_{22}$ & 0.110 & 0.301 & 0.245 & 0.033 \\
\hline December & $\mathrm{X}_{23}$ & 0.141 & 0.186 & 0.309 & 0.007 \\
\hline \multicolumn{6}{|l|}{ Two-month } \\
\hline November-December & $\mathrm{X}_{24}$ & 0.127 & 0.233 & 0.291 & 0.011 \\
\hline December-January & $\mathrm{X}_{25}$ & 0.152 & 0.154 & 0.338 & 0.003 \\
\hline January-February & $\mathrm{X}_{26}$ & 0.113 & 0.288 & 0.302 & 0.008 \\
\hline Three-month & & & & & \\
\hline October-November-December & $\mathrm{X}_{27}$ & 0.127 & 0.233 & 0.291 & 0.011 \\
\hline November-December-January & $\mathrm{X}_{28}$ & 0.140 & 0.189 & 0.315 & 0.006 \\
\hline December-January-February & $X_{29}$ & 0.123 & 0.249 & 0.309 & 0.007 \\
\hline January-February-March & $\mathrm{X}_{30}$ & 0.083 & 0.434 & 0.250 & 0.029 \\
\hline Mean total precipitation & & & & & \\
\hline One-month & & & & & \\
\hline January & $\mathrm{X}_{31}$ & 0.454 & $<0.001$ & 0.508 & $<0.001$ \\
\hline February & $\mathrm{X}_{32}$ & 0.433 & $<0.001$ & 0.492 & $<0.001$ \\
\hline March & $X_{33}$ & 0.415 & $<0.001$ & 0.476 & $<0.001$ \\
\hline April & $X_{34}$ & 0.422 & $<0.001$ & 0.501 & $<0.001$ \\
\hline May & $X_{35}$ & 0.415 & $<0.001$ & 0.445 & $<0.001$ \\
\hline June & $X_{36}$ & 0.397 & $<0.001$ & 0.440 & $<0.001$ \\
\hline July & $X_{37}$ & 0.309 & 0.003 & 0.252 & 0.028 \\
\hline August & $\mathrm{X}_{38}$ & 0.456 & $<0.001$ & 0.461 & $<0.001$ \\
\hline September & $\mathrm{X}_{39}$ & 0.394 & $<0.001$ & 0.484 & $<0.001$ \\
\hline October & $\mathrm{X}_{40}$ & 0.342 & 0.001 & 0.433 & $<0.001$ \\
\hline November & $\mathrm{X}_{41}$ & 0.431 & $<0.001$ & 0.487 & $<0.001$ \\
\hline December & $X_{42}$ & 0.461 & $<0.001$ & 0.485 & $<0.001$ \\
\hline Two-month & & & & & \\
\hline October-November & $\mathrm{X}_{43}$ & 0.404 & 0.001 & 0.500 & $<0.001$ \\
\hline November-December & $X_{44}$ & 0.449 & $<0.001$ & 0.523 & $<0.001$ \\
\hline December-January & $\mathrm{X}_{45}$ & 0.462 & $<0.001$ & 0.533 & $<0.001$ \\
\hline January-February & $X_{46}$ & 0.446 & $<0.001$ & 0.531 & $<0.001$ \\
\hline February-March & $X_{47}$ & 0.426 & $<0.001$ & 0.518 & $<0.001$ \\
\hline March-April & $\mathrm{X}_{48}$ & 0.419 & $<0.001$ & 0.520 & $<0.001$ \\
\hline April-May & $X_{49}$ & 0.422 & $<0.001$ & 0.505 & $<0.001$ \\
\hline October-November & $X_{50}$ & 0.412 & $<0.001$ & 0.471 & $<0.001$ \\
\hline Three-month & & & & & \\
\hline October-November-December & $\mathrm{X}_{51}$ & 0.449 & $<0.001$ & 0.523 & $<0.001$ \\
\hline November-December-January & $X_{52}$ & 0.452 & $<0.001$ & 0.529 & $<0.001$ \\
\hline December-January-February & $\mathrm{X}_{53}$ & 0.456 & $<0.001$ & 0.532 & $<0.001$ \\
\hline January-February-March & $X_{54}$ & 0.438 & $<0.001$ & 0.527 & $<0.001$ \\
\hline February-March-April & $X_{55}$ & 0.425 & $<0.001$ & 0.523 & $<0.001$ \\
\hline March-April-May & $\mathrm{X}_{56}$ & 0.422 & $<0.001$ & 0.510 & $<0.001$ \\
\hline April-May-June & $X_{57}$ & 0.421 & $<0.001$ & 0.501 & $<0.001$ \\
\hline
\end{tabular}

a Symbols: $r=$ correlation coefficient and $P=$ probability. Significant $P$ values $(<0.05)$ are highlighted in bold. 
hosts for P. neglectus and P. thornei (44). An annual presence of a host and an ample amount of soil moisture are likely to contribute to the support of high nematode populations in soil. About $70 \%$ of sampled fields were infested by Pratylenchus spp. in the annualcrop-fallow-transition zone.

Winter wheat-fallow rotation is typical in this region that receives low precipitation ( $<340 \mathrm{~mm}$ per year) (39). Absence of a host plant during the fallow period may reduce the nematode populations in soil, but if the fallow period is compromised by volunteer crop plants or other weed species, then these plants can host nematode multiplication (46). Many broadleaf and narrow-leaf weeds were found to be good hosts for these nematodes in Australia and the United States $(45,55,56)$. High nematode numbers detected in fallow fields in our study also support this explanation.

The incidence of Pratylenchus spp. declined in hot and dry parts of the state. Smiley et al. (47) showed that greater nematode numbers were present in the deeper soil profile in the dry region of the PNW. Sampling only the top $25 \mathrm{~cm}$ of soil in this study may have missed nematodes present in the deeper soil profile. In addition, spring precipitation in eastern Washington during 2010 and 2011 was higher than in previous years, with some locations receiving record rainfall (35; Table 1). The soil was cool and wet in both years, and it is likely that the cool temperature prevented the movement of nematodes from deeper in the soil profile. Insignificant survival of $P$. neglectus and $P$. penetrans at subzero temperature of $-2^{\circ} \mathrm{C}$ was also described previously in North America (51). The damage threshold for $P$. neglectus and $P$. thornei has been reported at nearly 2,000 nematodes $/ \mathrm{kg}$ of soil (44). This study showed only a few fields with more than 2,000 nematodes per $1,000 \mathrm{~cm}^{3}$ of soil. The shallow soil sampling method used in this study may be partly responsible for lower densities of nematodes.

The cereal cyst nematode (H. avenae), stunt nematode (Tylenchorhynchus spp.), pin nematode (Paratylenchus spp.), and Columbia root-knot nematode ( $M$. chitwoodi) were other plant-parasitic nematodes recovered from wheat fields in eastern Washington. The stunt nematode (Tylenchorhynchus spp., 27\%) was detected at more sites as compared with the cereal cyst nematode (12\%), pin nematode $(12 \%)$, and Columbia root-knot nematode $(<1 \%)$. Smiley et al. (46) also described these nematodes from dryland wheatproduction fields of the PNW. Different species of Tylenchorhynchus can infest and damage many crops such as corn, soybean, wheat, and sorghum (32).
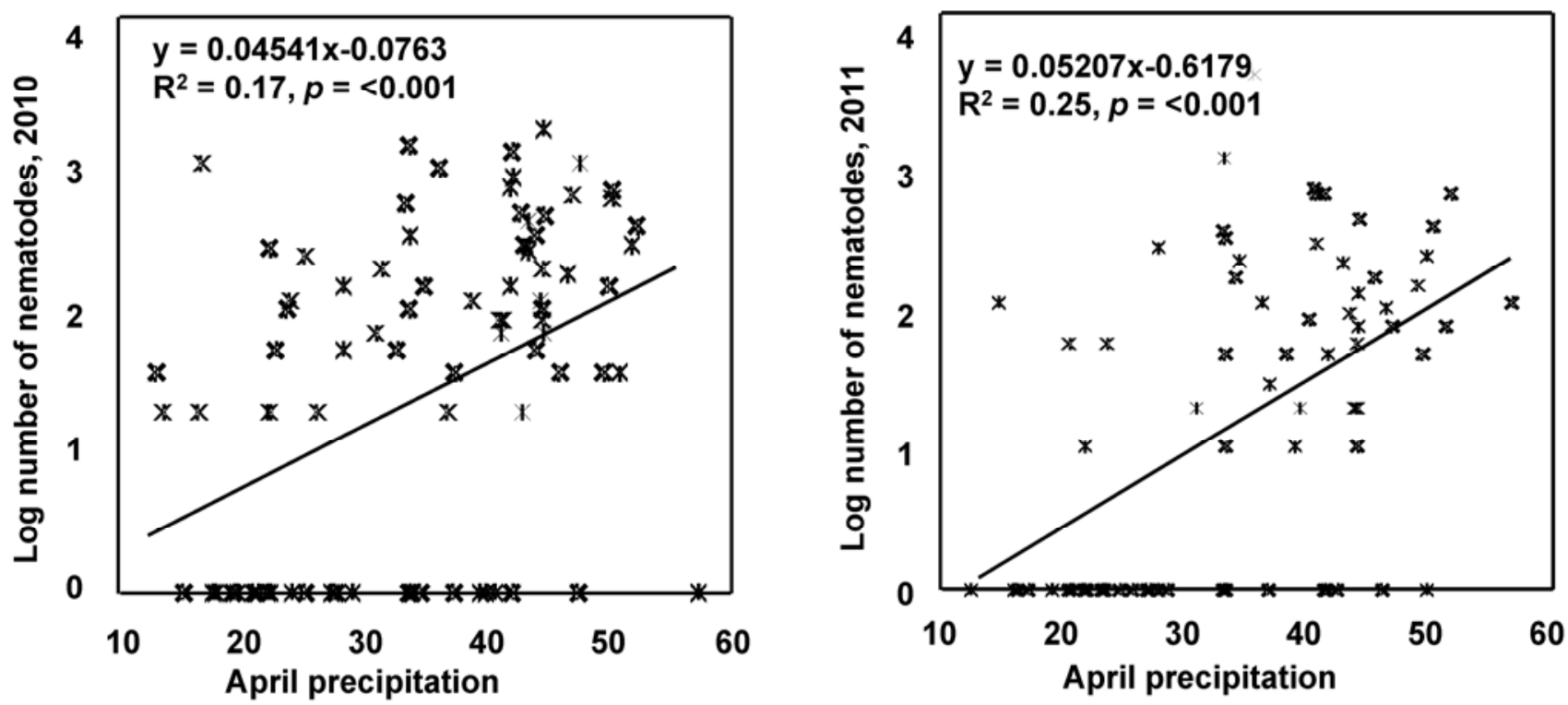

Fig. 3. Relationship between April precipitation (mm) and late-spring Pratylenchus spp. density in soil.
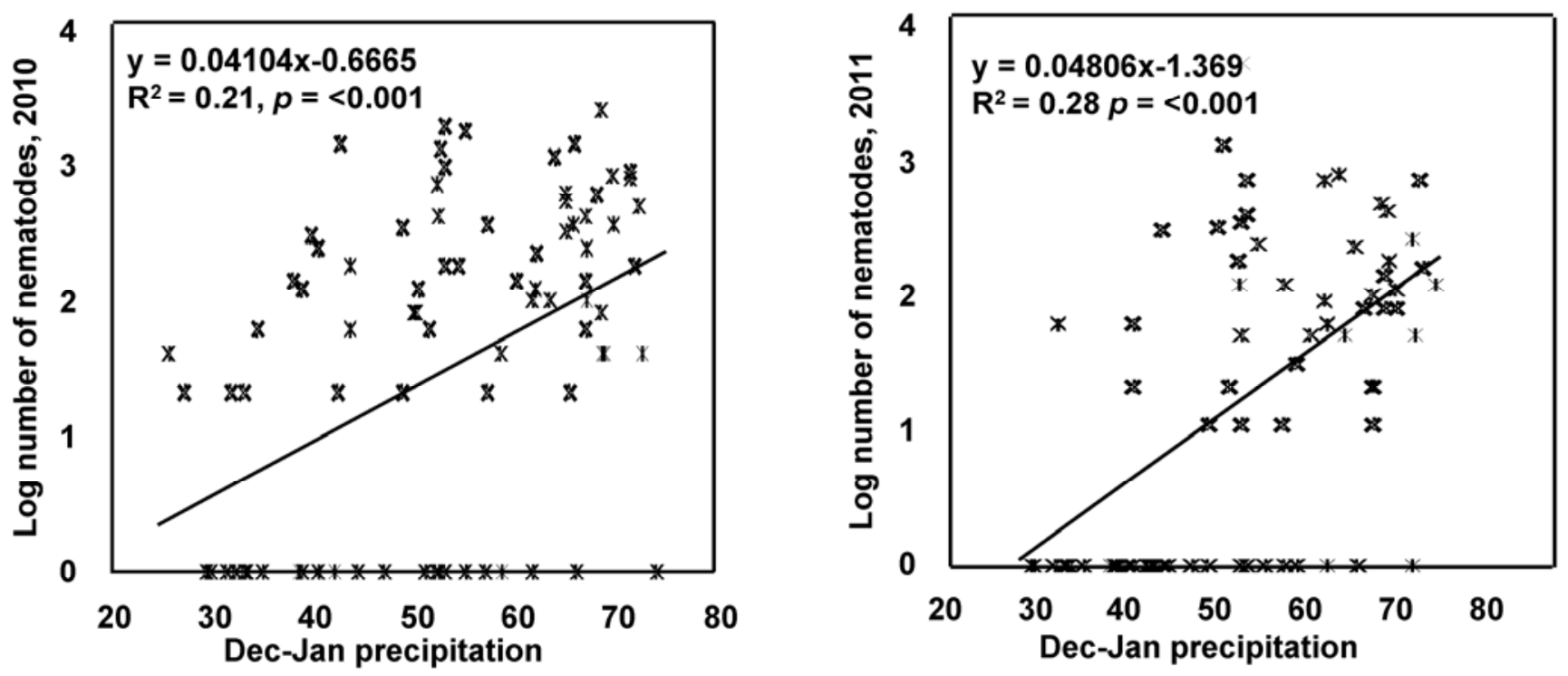

Fig. 4. Relationship between December-to-January precipitation $(\mathrm{mm})$ and late-spring Pratylenchus spp. density in soil. 
Fifty-seven weather variables derived from the past 31 years (1979 to 2010) were significantly correlated with either 1 year's or both years' density of Pratylenchus spp. Maximum air temperature during late spring to early fall was significantly negatively correlated with 2010 and 2011 density of Pratylenchus spp. The distribution of plant-parasitic nematodes, like other plant pathogens, is influenced by many factors such as local climate (air temperature, precipitation, drought, and so on), soil $\mathrm{pH}$, soil texture, cropping system, different tillage practices, and host tolerance and resistance $(6,16,26,31)$. Average maximum air temperature during summer was often recorded around $30^{\circ} \mathrm{C}$ in the survey sites. In this study, nematode densities in the majority of the survey fields were correlated with air temperature of nearly $22^{\circ} \mathrm{C}$. Optimum soil temperature for development of many Pratylenchus spp. is between 25 and $30^{\circ} \mathrm{C}(2,7)$. In addition, the temperatures in the soil will be much more buffered from extremes than the air temperature. Winter temperature was significantly correlated with nematode density during 2011. Moreover, winter freezing temperature may limit the survival of nematodes in soil. Reduction in populations of Meloidogyne spp. during winter has been documented in North America (4).
In both years, nematode densities were significantly correlated with monthly precipitation as well as with 2-month and 3-month precipitation periods from October to June. The moist soil environment in the winter creates favorable conditions for many soil microorganisms. Nematodes are organisms that migrate in the soil environment through the water phase. Hatching and movement of nematodes become greatest when soil moisture is at field capacity. Presence of favorable soil moisture and soil temperature causes maximum nematode activity (57). Survival and reproduction of $P$. penetrans was largely reduced in very low or very high soil moisture (20). In addition, vertical movements of many species of Pratylenchus have been observed in response to moisture gradients $(24,50)$. Fields with no detectable Pratylenchus spp. were observed more frequently in low-precipitation areas in both years of this study, although there was poor association between nematode density and precipitation in general (Figs. 3 and 4).

Density of Pratylenchus spp. in 2010 was significantly correlated with the density in 2011. The majority of plant-parasitic nematodes have been observed to be distributed variably within fields (5). Smiley et al. (46) showed that crop frequency and rotation are
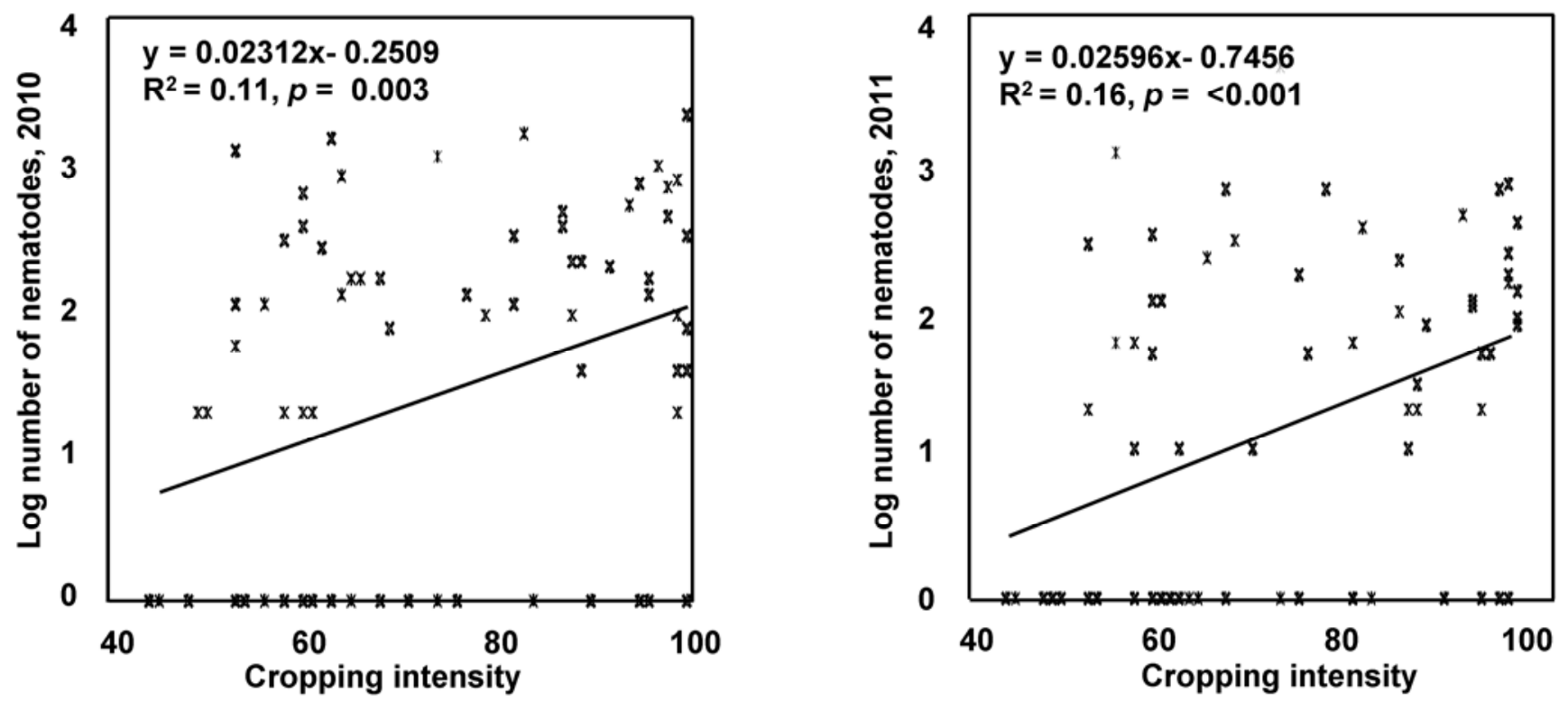

Fig. 5. Relationship between cropping intensity (\%) and late-spring Pratylenchus spp. density in soil.

Table 3. Multivariate models to describe the relationship between precipitation and temperature variables and Pratylenchus spp. density in $2010^{\mathrm{a}}$

\begin{tabular}{lccccl}
\hline \multicolumn{1}{c}{ Models } & $\boldsymbol{P}$ & $\boldsymbol{R}^{\mathbf{2}} \mathbf{a d j}(\boldsymbol{\%})$ & Mallows' $\mathbf{C}_{\mathbf{p}}$ & PRESS & \multicolumn{1}{c}{ VIF } \\
\hline$Y=0.053+0.125 X_{38}-0.224 X_{43}+0.0530 X_{45}+0.157 X_{54}$ & $<0.001$ & 27.2 & 5.0 & 97.3 & $8.0 X_{38}, 62.9 X_{43}, 24.1 X_{45}, 76.7 X_{54}$ \\
$Y=-0.409-0.185 X_{43}+0.0717 X_{45}+0.143 X_{54}$ & $<0.001$ & 25.0 & 6.6 & 99.7 & $57.8 X_{43}, 22.6 X_{45}, 76.0 X_{54}$ \\
$Y=0.472+0.148 X_{38}-0.226 X_{43}+0.209 X_{54}$ & $<0.001$ & 26.5 & 4.8 & 99.9 & $7.5 X_{38}, 62.9 X_{43}, 57.8 X_{54}$ \\
$Y=0.076-0.178 X_{43}+0.214 X_{54}$ & $<0.001$ & 22.9 & 8.1 & 99.9 & $57.7 X_{43}, 57.7 X_{54}$ \\
$Y=-0.817-0.0767 X_{43}+0.107 X_{45}$ & $<0.001$ & 23.0 & 8.0 & 99.9 & $17.7 X_{43}, 17.7 X_{45}$ \\
\hline
\end{tabular}

${ }^{\text {a }} P=$ probability, $R^{2}$ adj $=$ adjusted coefficient of multiple determination for multiple-variable models, PRESS = prediction sum of squares, and VIF $=$ variance inflation factor.

Table 4. Multivariate models to describe the relationship between precipitation and temperature variables and Pratylenchus spp. density in $2011^{\mathrm{a}}$

\begin{tabular}{|c|c|c|c|c|c|}
\hline Models & $\boldsymbol{P}$ & $\begin{array}{c}R^{2} \text { adj } \\
(\%)\end{array}$ & $\begin{array}{c}\text { Mallows' } \\
\mathbf{C}_{\mathrm{p}}\end{array}$ & PRESS & VIF \\
\hline$Y=4.59+0.185 X_{40}-0.203 X_{39}+0.0854 X_{45}-0.273 X_{10}+0.811 X_{25}$ & $<0.001$ & 41.2 & 6.0 & 60.5 & $14.7 X_{40}, 20 X_{39}, 8.2 X_{45}, 20.1 X_{10}, 26.9 X_{25}$ \\
\hline$Y=-2.43+0.169 X_{40}-0.143 X_{39}+0.0688 X_{45}+0.358 X_{10}$ & $<0.001$ & 38.6 & 8.1 & 62.6 & $14.5 X_{40}, 13.6 X_{39}, 7.1 X_{45}, 1.6 X_{10}$ \\
\hline$Y=1.72+0.186 X_{40}-0.185 X_{39}+0.0795 X_{45}+0.487 X_{25}$ & $<0.001$ & 41.4 & 4.7 & 59.8 & $14.7 X_{40}, 16.7 X_{39}, 7.4 X_{45}, 2.1 X_{25}$ \\
\hline$Y=-2.38-0.0741 X_{39}+0.0894 X_{45}+0.277 X_{10}$ & $<0.001$ & 35.5 & 10.9 & 64.9 & $6.3 X_{39}, 5.7 X_{45}, 1.3 X_{10}$ \\
\hline$Y=0.802-0.102 X_{39}+0.0996 X_{45}+0.376 X_{25}$ & $<0.001$ & 37.5 & 8.5 & 62.9 & $7.9 X_{39}, 6.3 X_{45}, 1.7 X_{25}$ \\
\hline$Y=-0.251+0.0429 X_{45}+0.181 X_{25}$ & $<0.001$ & 30.6 & 16.1 & 69.7 & $1.1 X_{45}, 1.1 X_{25}$ \\
\hline$Y=-1.95+0.0455 X_{45}+0.178 X_{10}$ & $<0.001$ & 31.2 & 15.3 & 68.8 & $1 X_{45}, 1 X_{10}$ \\
\hline
\end{tabular}

a $P=$ probability, $R^{2}$ adj = adjusted coefficient of multiple determination for multiple-variable models, PRESS = prediction sum of squares, and VIF $=$ variance inflation factor. 
significant factors correlated with high nematode densities in soil. Crop intensity measures the number of crops per year in a given field. Nematode densities in this study were significantly correlated with increased cropping intensity. Continuous presence of host plants helps to maintain multiple generations of nematodes in soil.

We and others have shown that Pratylenchus spp. present in the low-precipitation regions of the PNW have wide host ranges and can infect not only commonly grown crops (wheat, barley, brassicas, and legumes) in this region but also many monocot or dicot weeds and volunteer plants $(43,46)$. This indicates adaptation of these nematodes in different cropping systems and agroclimatic conditions of eastern Washington. Because of their damage to plant roots, the negative effects of these nematodes are often greater under limited-soil-moisture conditions than in irrigated or highprecipitation conditions. Management of these nematodes using chemicals is not economically feasible and, importantly, no nematicides have been registered for small grains in the PNW. Therefore, management options are limited to cultural practices and host tolerance or host resistance.

The population of plant-parasitic nematodes in soil is determined by different weather variables, host species, and edaphic factors, where the incidence and nematode densities need to be known before applying any management decisions. Temperature and moisture have great influence on soil microorganisms, especially in rainfed production systems. Mathematical models have been derived to anticipate damage and crop loss induced by many plant-parasitic nematodes $(12,13,41,53)$. Temperature and precipitation have previously been used to predict the activity of nematodes in the soil. Temperature rather than soil moisture has been shown to be more significant in the case of root endoparasitic nematodes because nematodes become independent of soil moisture as soon as they penetrate into plant roots $(16,18)$. Because Pratylenchus spp. can feed both ectoparasitically and endoparasitically, both temperature and precipitation are similarly important and affect both the nematode directly and, indirectly, its plant host, as we have shown here. Winter precipitation was found to be significantly correlated with both years' nematode populations and was selected as explanatory variables in the regression models. This finding is similar to other studies that showed that precipitation influenced nematode populations in soil $(8,16,21)$. By using these multivariate models, we showed how specific 1- and 2-month variables of temperature and precipitation derived from 31-year means can partially explain the distribution of these nematodes across a wide region of varying agroclimatic zones. It was also apparent that the strength of these models varied between years, most likely a reflection of the deviations from these long-term means.

\section{Acknowledgments}

This study was supported by a grant from the Washington Grain Commission and the O. A. Vogel Foundation, Washington State University. We thank J. Nicol of the International Maize and Wheat Improvement Center (CIMMYT) in Turkey for funding from the US-AID collaboration, as part of the global initiative "Integrated Management of Soil-Borne Pathogens and Pests for Resource-Poor Farmers of Rainfed Wheat"; and D. Sharma-Poudyal for assistance with modeling.

\section{Literature Cited}

1. Abatzoglou, J. T. 2012. Development of gridded surface meteorological data for ecological applications and modelling. Int. J. Climatol. Online publication. doi:10.1002/joc.3413.

2. Acosta, N., and Malek, R. B. 1979. Influence of temperature on population development of eight species of Pratylenchus on soybean. J. Nematol. 11:229-232.

3. Baldwin, J. G., Nadler, S. A., and Adams, B. J. 2004. Evolution of plant parasitism among nematodes. Annu. Rev. Phytopathol. 42:83-105.

4. Belair, G. 1985. Winter survival of the northern root-knot nematode Meloidogyne hapla in organic soil. Can. J. Plant Sci. 65:435-439.

5. Boag, B., and Topham, P. B. 1984. Aggregation of plant parasitic nematodes and Taylor's power law. Nematologica 30:348-357.

6. Cadet, P., Masse, D., and Thioulouse, J. 2005. Relationships between plantparasitic nematode community, fallow duration and soil factors in the Sudano-Sahelian area of Senegal. Agric. Ecosyst. Environ. 108:302-317.

7. Castillo, P., Trapero-Casas, J. L., and Jimenez-Diaz, R. M. 1995. Effect of time, temperature, and inoculum density on reproduction of Pratylenchus thornei in carrot disk cultures. J. Nematol. 27:120-124.

8. Cooke, D. A. 1973. The effect of plant parasitic nematodes, rainfall and other factors on docking disorder of sugar beet. Plant Pathol. 22:161-170.

9. Dickerson, O. J. 1979. The effects of temperature on Pratylenchus scribneri and $P$. alleni populations on soybeans and tomatoes. J. Nematol. 11:23-26.

10. Douglas, C. L., Rickman, R. W., Jr., Klepper, B. L., Zuzel, J. F., and Wysocki, D. J. 1992. Agroclimatic zones for dryland winter wheat producing areas of Idaho, Washington, and Oregon. Northwest Sci. 66:26-34.

11. Duveiller, E., Singh, R. P., and Nicol, J. M. 2007. The challenges of maintaining wheat productivity: Pests, diseases, and potential epidemics. Euphytica 157:417-430.

12. Ehwaeti, M. E., Elliott, M. J., McNicol, J. M., Phillips, M. S., and Trudgill, D. L. 2000. Modeling nematode population growth and damage. Crop. Prot. 9:739-745.

13. Ferris, H. 1985. Densities-dependent nematode seasonal multiplication rates and overwinter survivorship: a critical point model. J. Nematol. 17:93-100.

14. Ferris, J. M. 1970. Soil temperature effects on onion seedling injury by Pratylenchus penetrans. J. Nematol. 2:248-251.

15. Griffin, G. D. 1996. Importance of soil texture to the pathogenicity of plant parasitic nematodes on rangeland grasses. Nematropica 26:27-37.

16. Griffin G. D., Asay, K. H., and Horton, W. H. 1996. Factors affecting population trends of plant-parasitic nematodes on rangeland grasses. J. Nematol. 28:107-114.

17. Ingham, R. E. 1994. Nematodes. Pages 459-490 in: Methods of Soil Analysis, Part 2. Microbiological and Biochemical Properties. R. W. Weaver, ed. American Society of Agronomy, Madison, WI.

18. Jones, F. G. W. 1975. Accumulated temperature and rainfall as measures of nematode development and activity. Nematologica 21:62-70.

19. Jones, F.G.W., Larbey, D. W., and Parrott, D. M. 1969. The influence of soil structure and moisture on nematodes, especially Xiphinema, Longidorus, Trichodorus and Heterodera spp. Soil Biol. Biochem. 1:153-158.

20. Kable, P. F., and Mai, W. F. 1968. Influence of soil moisture on Pratylenchus penetrans. Nematologica 14:101-122.

21. Kimpinski, J., Wallace, H. R., and Cunningham, R. B. 1976. Influence of some environmental factors on populations of Pratylenchus neglectus in wheat. J. Nematol. 8:310-314.

22. Kimpinski, J., and Willis, C. B. 1981. Influence of soil temperature and $\mathrm{pH}$ on Pratylenchus penetrans and P. crenatus in alfalfa and timothy. J. Nematol. 13:333-338.

23. Kutner, M. H., Nachtsheim, C. J., Neter, J., and Li, W. 2005. Pages 384-420 in: Applied Linear Statistical Models. McGraw-Hill, New York.

24. Mani, A. 1999. Survival of the root-lesion nematode Pratylenchus jordanensis Hashim in a fallow field after harvest of alfalfa. Nematology 1:7984.

25. Marshall, B., Boag, B., McNicol, J. W., and Neilson, R. 1998. A comparison of the spatial distributions of three plant-parasitic nematode species at three different scales. Nematologica 44:303-320.

26. McSorley, R. 2003. Adaptations of nematodes to environmental extremes. Fla. Entomol. 86:138-142.

27. Mediavilla, F. A. M., Landrum, F., and Shah, V. 2008. A comparison of the coefficient of predictive power, the coefficient of determination and AIC for linear regression. Pages 1261-1266 in: Proc. 39th Annu. Meet. Decision Sciences Institute. J. E. Kendall, ed. Decision Sciences Institute, Atlanta.

28. Moens, M., and Perry, R. L. 2009. Migratory plant endoparasitic nematodes: A group rich in contrasts and divergence. Annu. Rev. Phytopathol. 47:313-332.

29. Nicol, J. M., and Ortiz-Monasterio, I. 2004. Effects of the root-lesion nematode, Pratylenchus thornei, on wheat yields in Mexico. Nematology 6:485493.

30. Nicol, J. M., and Rivoal, R. 2008. Global knowledge and its application for the integrated control and management of nematodes on wheat. Pages 251294 in: Integrated Management and Biocontrol of Vegetable and Grain Crops Nematodes, A. Ciancio, and K. G. Mukerji, eds. Springer, Dordrecht, The Netherlands.

31. Norton, D. C. 1979. Relationship of physical and chemical factors to populations of plant-parasitic nematodes. Annu. Rev. Phytopathol. 17:279-299.

32. O'Bannon, J. H., Esser, R. P., and Inserra, R. N. 1991. Tylenchorhynchus species as crop damaging parasitic nematodes. Nematol. Circ. 190:1-4.

33. Ogbuji, R. O. 1978. Effects of Meloidogyne incognita and Pratylenchus brachyurus singly and combined of growth of Nigerian Tobacco (NTC 5). Nematropica 8:62-66.

34. Orion, D., Amir, J., and Krikun, J. 1984. Field observations on Pratylenchus thornei and its effects on wheat under arid conditions. Rev. Nematol. 7:341345.

35. OWSC (Office of the Washington State Climatologist). 2011. State of Washington, Olympia. http://www.climate.washington.edu/newsletter/

36. Paulitz, T. C. 2006. Low input no-till cereal production in the Pacific Northwest of the U.S.: The challenges of root diseases. Eur. J. Plant Pathol 115:271-281.

37. Paulitz, T. C., Okubara, P. A., and Schroeder, K. L. 2009. Integrated control of soilborne pathogens of wheat. Pages 229-245 in: Recent Developments in Management of Plant Diseases. U. Gisi, I. Chet, and M. L. Gullino, eds. Springer, Dordrecht, The Netherlands. 
38. Riga, E., Porter, L. D., Mojtahedi, H., and Erickson, D. 2008. Pratylenchus neglectus, P. thornei, and Paratylenchus hamatus nematodes causing yield reduction to dryland peas and lentils in Idaho. Plant Dis. 92:979.

39. Schillinger, W. F., Kennedy, A. C., and Young, D. L. 2007. Eight years of annual no-till cropping in Washington's winter wheat-summer fallow region. Agric. Ecosyst. Environ. 120:345-358.

40. Schillinger, W. F., and Papendick, R. I. 2008. Then and now: 125 years of dryland wheat farming in the inland Pacific Northwest. Agron. J. 100:S166S182.

41. Seinhorst, J. W. 1965. The relation between nematode densities and damage to plants. Nematologica 11:137-154.

42. Sharma-Poudyal, D., and Chen, X. M. 2011. Models for predicting potential yield loss of wheat caused by stripe rust in the U.S. Pacific Northwest. Phytopathology 101:544-554.

43. Smiley, R. W. 2009. Root-lesion nematodes reduce yield of intolerant wheat and barley. Agron. J. 101:1322-1335.

44. Smiley, R. W. 2010. Root-lesion nematodes: Biology and management in Pacific Northwest wheat cropping systems. PNW Ext. Bull. 617. Oregon State University, Corvallis.

45. Smiley, R. W., and Machado, S. 2009. Pratylenchus neglectus reduces yield of winter wheat in dryland cropping systems. Plant Dis. 93:263-271.

46. Smiley, R. W., Merrifield, K., Patterson, L. M., Whittaker, R. G., Gourlie, J. A., and Easley, S. A. 2004. Nematodes in dryland field crops in the semiarid Pacific Northwest USA. J. Nematol. 36:54-68.

47. Smiley, R. W., Sheedy, J. G., and Easley, S. A. 2008. Vertical distribution of Pratylenchus spp. in silt loam soil and Pacific Northwest dryland crops. Plant Dis. 92:1662-1668.

48. Strausbaugh, C. A., Bradley, C. A., Koehn, A. C., and Forster, R. L. 2004. Survey of root diseases of wheat and barley in southeastern Idaho. Can. J. Plant Pathol. 26:167-176.

49. Thompson, J. P., Owen, K. J., Stirling, G. R., and Bell, M. J. 2008. Rootlesion nematodes (Pratylenchus thornei and P. neglectus): A review of re- cent progress in managing a significant pest of grain crops in northern Australia. Australas. Plant Pathol. 37:235-242.

50. Tobar, A., Valor, H., and Talavera, M. 1996. On the field anhydrobiotic ability of Pratylenchus thornei and Merlinius brevidens. Fund. Appl. Nematol. 19:43-46.

51. Townshend, J. L. 1973. Survival of Pratylenchus penetrans and P. minyus in two Ontario soils. Nematologica 19:35-42.

52. USDA-NASS. 2010. USDA-NASS, Washington, DC. http://www.nass usda.gov/

53. van der Putten, W. H., Cook, R., Costa, S., Davies, K. G., Fargette, M Freitas, H., Hol, W. H. G., Kerry, B. R., Maher, N., Mateille, T., Moens, M., de la Pena, E., Piskiewicz, A. M., Raeymaekers, A. D. W., Rodriguez-Echeverria, S., and van der Wurff, A. W. G. 2006. Nematode interactions in nature: Models for sustainable control of nematode pests of crop plants? Adv. Agron. 89:227-260.

54. Vanstone, V. A., Hollaway, G. J., and Stirling, G. R. 2008. Managing nematode pests in the southern and western regions of the Australian cereal industry: Continuing progress in a challenging environment. Australas. Plant Pathol. 37:220-234.

55. Vanstone, V. A., and Russ, M. H. 2001. Ability of weeds to host the rootlesion nematodes Pratylenchus neglectus and P. thornei I. Grass weeds. Australas. Plant Pathol. 30:245-250.

56. Vanstone, V. A., and Russ, M. H. 2001. Ability of weeds to host the rootlesion nematodes Pratylenchus neglectus and P. thornei II. broad-leaf weeds. Australas. Plant Pathol. 30:251-258.

57. Wallace, H. R. 1968. The dynamics of nematode movement. Annu. Rev. Phytopathol. 6:91-114.

58. Wallace, H. R. 1983. Interactions between nematodes and other factors on plants. J. Nematol. 15:221-227.

59. Zirakparvar, M. E., Norton, D. C., and Cox, C. P. 1980. Population increase of Pratylenchus hexincisus on corn as related to soil temperature and type. J. Nematol. 12:313-318. 